\title{
Economic evaluation of conservation tillage options for deciding the feasibility of their adoption
}

\author{
Rakesh Kumar*, Pramila Aggarwal and Amarendra Kumar ${ }^{1}$ \\ Division of Agricultural Physics, Indian Agricultural Research Institute, New delhi-110012, INDIA \\ ${ }^{1}$ Department of Plant Pathology, Bihar Agricultural University, Bhagalpur- 813210 (Bihar), INDIA \\ ${ }^{*}$ Corresponding author. E-mail: rbinnu@gmail.com \\ Received: April 14, 2015; Revised received: December 20, 2015; Accepted: April 3, 2016
}

\begin{abstract}
The present experiment was conducted to evaluate two important conservation tillage practices namely zero tillage in wheat and bed planting for growing vegetables for deciding the economic feasibility of their adoption in Gohana and Kharkhoda block of Sonipat district in Haryana. In first scenario, comparison were made between Puddled transplanted rice followed by conventional tilled wheat (PTR - CTW), and puddled transplanted rice followed by zero till wheat (PTR - ZTW). In second scenario, conventionally tilled Jowar in kharif followed by conventionally tilled wheat system (CTJ - CTW) was compared with vegetables on beds in both seasons (BV-BV). Sowing of wheat by zero till drill in PTR - ZTW system, decreased cost of cultivation by $21 \%$ over its value of Rs 20688 in PTR - CTW treatment; increased grain yield by $5 \%$ over the grain yield of $5.99 \mathrm{t} \mathrm{ha}^{-1}$ in PTR - CTW treatment. The B: C ratio of PTR - ZTW was 4.65 while that of PTR - CTW treatment was 3.24, which indicated economic viability of zero tillage practice. While in case of cauliflower in BV-BV system, the total cost of cultivation was estimated at Rs 51500/ha and net returns of Rs 38072/ha i.e an increased net return of 5.8 times over the net return of Rs 46223.5 in CTJ - CTW treatment. The B: C ratio of BV-BV was 5.21, while that of CTJ - CTW treatment was 2.35. Thus, it was concluded that in rabi season, cauliflower on beds and zero till wheat are most economically viable options in this temporary waterlogged regions of Yamuna basin.
\end{abstract}

Key words: Bed planting, Cauliflower, Economics, Wheat, Zero tillage

\section{INTRODUCTION}

Rice-wheat system is the predominant cropping system of Indo-Gangetic Plains (IGP) (Gupta et al., 2010). Both crops of this cropping system are fertility exhaustive and need more water, labour, time, heavy farm machineries and other expenditure. Continued puddling for rice cultivation over decades has led to deterioration of soil physical properties through structural breakdown of soil aggregates and capillary pores and clay dispersion thereby restricting germination and rooting of succeeding crops (Gangwar et al., 2006). Expected yield of the crop cannot be more than $70 \%$ of the potential yield even under normal or higher levels of fertilizer and water inputs (Kumar et al., 2014). Evidence from longterm experiments shows that crop yields are stagnating and sometimes declining (Duxbury et al., 2000; Ladha et al., 2003). Therefore, it is imperative that alternate method of growing crops that are more water efficient and less labour intensive is to be developed to enable farmers to produce more with less cost of production. Agricultural technologies that can save resources reduce production costs and improve production, while sustaining environmental quality are therefore becoming increasingly important (Gupta et al., 2002; Hobbs and Gupta, 2003).
Zero tillage (ZT) as applied to the rice-wheat systems in the IGP has three distinctive features that distinguish it from related systems elsewhere (e.g. Ekboir, 2002; Erenstein, 2002, 2003). First, ZT is typically only applied to the wheat crop, with the subsequent rice crop still intensively tilled. Second, ZT wheat after rice does not necessarily entail an increased reliance on herbicide, reflecting that paddy rice fields are relatively weed free at harvest time. Third, ZT wheat does not necessarily imply the retention of crop residues as mulch.

Growing demand for vegetables induced by rising incomes and changing consumption patterns coupled with declining farm incomes due to rising costs and stagnating food grain productivity has necessitated diversification towards high-value crops cabbage, cauliflower, raddish, tomato, brinjal, chilli, pumpkin, okra etc in recent times. Apart from income enhancement, these high-value crops have potential to generate additional employment opportunities in farming due to their labour- intensive character (Weinberger and Lumpkin, 2006). Furrow irrigated reduced tillage bed planting system got wider adaptability in Indo Gangetic plains (IGP) of India (Hobbs and Gupta 2003, Timsina and Connor 2001). In this mechanized system of bed planting, both bed making and seeding 
of crops are done in single operation. For the next season, the same bed is renovated/reshaped. Generally, farmers growing Cabbage, cauliflower, raddish, Tomato, brinjal, chilli, Pumpkin, Okra and carrot etc on bed. Haryana produce 526.5 thousand tonnes of cauliflower in 2013-14 i.e 6\% of total production in India (NHB, 2014). Bed planting also created better soil physical environment all throughout the crop growth, which led to higher crop productivity (Sharma and Bhushan, 2001; Aggarwal and Goswami 2003). The present study was conducted in those farmers' fields who adopted conservation tillage practices to evaluate economic feasibility of these tillage system adoptions.

\section{MATERIALS AND METHODS}

A field survey was conducted to evaluate the economic viability of prevalent conservation tillage practices followed in rabi season in rabi (test crop i.e wheat and cauliflower) in Gohana and Kharkhoda block of Sonipat district in Haryana, India, located at $28^{\circ} 47^{\prime} 26.959^{\prime \prime}$ to $29^{\circ} 11^{\prime} 55.306^{\prime \prime}$ North latitude and $76^{\circ} 37^{\prime} 47.601$ " to $77^{\circ} 3^{\prime} 10.875$ " East longitudes. The climate of the district is characterized by the dryness of the air with an intensely hot summer and a cold winter. The selected villages for the study of bed plantings were Gohana, kanwali, Anwali, Biblan, Puthi and Rukhi and for zero tillage were Giwana, Jasrana, Jauli, Jharaut and Katwal. Generally four types of adopters are taken in consideration as follows.

Conventional versus Zero tillage system

$\begin{array}{ll}\text { Treatment Name } & \begin{array}{l}\text { Specification } \\ \text { Puddled transplanted rice followed } \\ \text { PTR - CTW }\end{array} \\ \text { by conventional tilled wheat } \\ \text { Puddled transplanted rice followed } \\ \text { by zero till wheat }\end{array}$

Conventional versus bed system

$\begin{array}{ll}\text { CTJ - CTW } & \begin{array}{l}\text { Conventionally tilled Jowar in kharif } \\ \text { followed by conventionally tilled wheat }\end{array} \\ \text { BV-BV } & \text { Vegetables on beds in both kharif and } \\ & \text { Rabi season. }\end{array}$

Ten farmers were selected for each treatment. They were statistically analysed under simple randomized block design.

Analysis of data: Benefit cost ratio is the quick and easiest method to determine the economic performance of farm business. It is ratio of total net monetary return from the crop and cost of cultivation. Cost of production was calculated by summing all the input items cost during crop raising. For calculating net return, income from the sale was deducted. Thus, the benefit cost analysis was carried out by using formula

$$
B / C \text { ratio }=\frac{\text { Net return }(R s)}{\text { Total input }(R s)}
$$

The data so generated during the course of present investigation were subjected to t-test for examining the significant differences between the treatments (Gomez and Gomez, 1984).

\section{RESULTS AND DISCUSSION}

Economics of cultivation

First scenario (Input cost): On comparing cost of cultivation for wheat under both tillage systems, it was observed that for cultivating one hectare of land, as compared to conventional system, under zero tillage there was a saving of Rs 1700 as no land preparation is required and also a saving of Rs 1200 due to less seed and labour requirement but there was an additional expenditure of Rs 672 due to more use of herbicide (Table1 and 2). Again there was a saving of one irrigation in zero tillage system which was equivalent to Rs 300 . Hence, comparison of overall cost of cultivation showed that there was saving of Rs 2828 in PTRZTW treatment.

Output yield and monetary return: In first scenario, in low lying lands of Yamuna basin in Sonipat district having fine textured soils, despite of puddling in kharif in both treatments, sowing of wheat by zero till drill in PTR - ZTW resulted in significantly higher grain (6.29 $\mathrm{t} \mathrm{ha}^{-1}$ ) in comparison to grain yield of PTR CTW (5.99 $\mathrm{t} \mathrm{ha}^{-1}$ ) (Table 5). The reason for higher grain yield in zero till wheat was mainly due to timely sowing of wheat in mid November, good seed germination due to presence of adequate moisture and addition of rotten crop residue in the soil in the form of humus which improved SOC and aggregation of root zone, thereby reducing the ill effects of puddling done for the previous rice crop. But in case of convention tillage system, sowing was done in mid December as the field became dry for tillage operations only in first week of December (Sharma et al., 2006). These findings are in close agreement with Singh et al. (2014). They reported that zero- tillage sowing was found to be most time saving (88\%) and energy efficient (79\%) as compared to conventional method of sowing. Wheat crop can be sown 10-15 days early as compared to conventional method of sowing. This will result in timely sowing of wheat crop and increase in yield.

Gross output in terms of monetary gain was higher by $5 \%$ in ZT wheat in comparison to $\mathrm{CT}$ wheat (Rs 87753.5). PTR - ZTW gave B:C ratio of 4.17 and net income of Rs $75,993.6 \mathrm{ha}^{-1}$, as against $\mathrm{B}: \mathrm{C}$ ratio of 3.24 and net income of Rs 67065.5/ha, hence proved more remunerative than other methods of crop establishment in case of wheat (Table 5). This was ascribed to higher grain yield and minimum cost of production. Though conventional sowing of wheat fetched higher gross return because of more cost of investment required in conventional sown wheat than zero tilled wheat. Kankanen et al. (2011) reported that ZT effects on savings for diesel, tractor time and cost for wheat cultivation are particularly robust in Haryana. Erenstein (2009) also reported that ZT's positive implica- 
Table 1. Estimation of cost of cultivation for Conventional wheat under PTR - CTW system.

\begin{tabular}{llll}
\hline S. N. & Operation & Rate / unit (Rs) & Cost (Rs /ha) \\
\hline A. & Input & & \\
1. & Land preparation & $500 / \mathrm{ha}$ & 500 \\
& (i) Ploughing & $500 / \mathrm{ha}$ & 1000 \\
& (ii) Discing (two) & $200 / \mathrm{ha}$ & 200 \\
& (iii) Planking & $150 /$ Men-day & 600 \\
2. & Layout (4 Men-day) & $35 / \mathrm{kg}$ & 3500 \\
3. & Seed (100 kg /ha) & $500 / \mathrm{ha}$ & 500 \\
4. & Sowing & & \\
5. & Inter-culture operations & $670 / \mathrm{kg}$ & 670 \\
& (i) Isoproturon (1.0 kg a.i. /ha) & $150 /$ Men-day & 150 \\
& (ii) Spray of isoproturon (1 Men-day) & & 4368 \\
6. & Fertilizer- NPK(120:60:40) & & \\
7. & Irrigations (3 irrigation) & $150 /$ ha & 450 \\
& (i) Water charges & $150 /$ Men-day & 450 \\
& (ii) labour charges (3 Men-day) & $150 /$ Men-day & 3000 \\
8. & Harvesting (20 Men-day) & & 300 \\
9. & Bagging & $150 /$ Men-day & 2000 \\
10. & Threshing charges and Cleaning (10 Men-day) & $500 /$ Month & 3000 \\
11 & Rental value of land 6 Months & & 20688 \\
\hline
\end{tabular}

Table 2. Estimation of cost of cultivation for zero tilled wheat under PTR - ZTW system.

\begin{tabular}{|c|c|c|c|c|}
\hline S. N. & Operation & & Rate / unit (Rs) & Cost (Rs /ha) \\
\hline A. & Input & & & \\
\hline 1. & Pre-emergence weedicide & Glyphosate @2.5lit/ha and labour charge (1 Man-day) & 300/lit & 900 \\
\hline 2. & Sowing & Seed drill@3 hr. & $200 / \mathrm{hr}$ & 600 \\
\hline 3. & Seed & $80 \mathrm{~kg} / \mathrm{ha}$ & $35 / \mathrm{kg}$ & 2800 \\
\hline 4. & Fertilizer cost & NPK (120:60:40) & & 4368 \\
\hline \multirow[t]{2}{*}{5.} & Herbicides & Isoproturon $(0.75 \mathrm{~kg}$ a.i. $/ \mathrm{ha})$ & $270 / \mathrm{kg}$ & 202 \\
\hline & & $\begin{array}{l}\text { 2,4-D (@0.5kg/ha) } \\
\text { Labour (2man/day) }\end{array}$ & $180 / \mathrm{kg}$ & $\begin{array}{l}90 \\
300\end{array}$ \\
\hline \multirow[t]{3}{*}{6.} & Irrigations (2 irrigation) & & & \\
\hline & (i) Water charges & & $150 / \mathrm{ha}$ & 300 \\
\hline & (ii) labour charges & (2 Men-day) & 150 / Men-day & 300 \\
\hline 7. & Harvesting & (20 Men-day) & 150 / Men-day & 3000 \\
\hline 8. & Threshing and Cleaning & & 150 / Men-day & 2000 \\
\hline 9. & Bagging & Labour (2 man-day) & & 300 \\
\hline \multirow[t]{2}{*}{10.} & Rental value of land & 6 Months & $500 /$ Month & 3000 \\
\hline & & & Total & 17860 \\
\hline
\end{tabular}

tions for yield and the other financial indicators were also statistically robust in Haryana

Second scenario

Input cost: On comparing cost of cultivation per hectare of land for conventional wheat and cauliflower on bed systems, it was observed that for conventionally tilled wheat, there was a saving of Rs 4150 as less land preparation is required and also a saving of Rs 8880 due to less use of herbicide (Tables 3 and 4). Besides, in bed planting system, there was an extra expenditure of Rs 12000 on pesticides and fertilizer use due to more frequency of their applications and more amounts per application as both were applied as foliar spray. Overall, there was more expenditure of Rs $31962 /$ ha in cauliflower cultivation on beds in com- parison to conventionally tilled wheat.

Output yield and monetary return: While in case of cauliflower in BV-BV system, the total cost of cultivation was estimated at Rs 51500/ha and net returns of Rs 38072/ha .Net return under BV-BV treatment was 5.8 times that in CTJ-CTW treatment (Table 5). The $\mathrm{B}$ : $\mathrm{C}$ ratio of $\mathrm{BV}-\mathrm{BV}$ was 5.21 while that of CTJ CTW treatment was 2.35. This shows that BV is a better option. The results are in close conformity with the findings of Sidhu et al. (2010) who reported higher net returns for cauliflower (Rs 38072/ha) and its faster price transmission.

\section{Conclusion}

Sowing of wheat by zero till drill in puddle trans- 
Table 3. Estimation of cost of cultivation for Conventional wheat in CTJ - CTW system.

\begin{tabular}{llll}
\hline S. N. & Operation & Rate / unit (Rs) & Cost (Rs /ha) \\
\hline A. & Input & & \\
1. & Land preparation & $500 / \mathrm{ha}$ & 500 \\
& (i) Ploughing & $500 / \mathrm{ha}$ & 1000 \\
& (ii) Discing (two) & $200 / \mathrm{ha}$ & 200 \\
& (iii) Planking & $150 /$ Men-day & 600 \\
2. & Layout (4 Men-day) & $35 / \mathrm{kg}$ & 3500 \\
3. & Seed (100 kg /ha) & $500 / \mathrm{ha}$ & 500 \\
4. & Sowing & & \\
5. & Inter-culture operations & $670 / \mathrm{kg}$ & 670 \\
& (i) Isoproturon (1.0 kg a.i. /ha) & $150 /$ Men-day & 450 \\
& (ii) Spray of isoproturon (3 Men-day) & & 4368 \\
& Fertilizer- NPK(120:60:40) & & \\
6. & Irrigations (3 irrigation) & $150 / \mathrm{ha}$ & 450 \\
& (i) Water charges & $150 /$ Men-day & 450 \\
& (ii) labour charges (6 Men-day) & $150 /$ Men-day & 1650 \\
7. & Harvesting (11 Men-day) & & 300 \\
8. & Bagging & $150 /$ Men-day & 2000 \\
9. & Thresting and Cleaning (10 Men-day) & $500 /$ Month & 3000 \\
10. & Rental value of land 6 Months & & 19638 \\
\hline
\end{tabular}

Table 4. Estimation of cost of cultivation vegetable (cauliflower) grown on bed in BV-BV system.

\begin{tabular}{lll}
\hline S. N. & Operation & Cost (Rs/ha) \\
\hline Input & Land preparation (Bed planter) & 6000 \\
& Nursery and planting sowing (Manure@ 8-10 kg/sq m), biofertilizer, gap & 10000 \\
& filling) Bavistin @ 15-20 gm/10 liter of water & \\
& Seed treatment (Thiram @ 2g/kg soil chemical - +biocontrol- Trichoderma & \\
& viride in soil @ 1.2kg/ha) & 10000 \\
& Weeding (herbicide, manual) & 12000 \\
& Plant protection (Insect and disease) & 8500 \\
& Fertilizer and Manure (100:100:50::NPK), foliar spray of urea (1-2\%) PSB+ & \\
& Rhizobium+ Azotobacter/Azospirillum & 5000 \\
& Wages (irrigation, interculture) & 51500 \\
& TOTAL & $320000($ Rs $10 /-)$ \\
& Yield - 32000 flowers & \\
Net income & (Market price @ Rs 10-15) & 268500 \\
\hline
\end{tabular}

Table 5. Economics of wheat and cauliflower cultivation as influenced by various tillage systems.

\begin{tabular}{lllllll}
\hline Treatments & Grain yield (t/ha) & Straw yield (t/ha) & Input (Rs) & Output (Rs) & $\begin{array}{l}\text { Net return } \\
\text { (Rs) }\end{array}$ & $\begin{array}{l}\text { B:C ratio (Net } \\
\text { return/input) }\end{array}$ \\
\hline PTR-CT & 5.99 & 7.18 & 20688 & 87753.5 & 67065.5 & 3.24 \\
PTR-ZTW & 6.29 & 7.68 & 17860 & 92353.6 & 74493.2 & 4.17 \\
t-test & S & S & & & & \\
CTJ-CTW & 4.45 & 5.79 & 19638 & 65861.5 & 46223.5 & 2.35 \\
BV-BV & 32000 flowers & - & 51500 & 320000 & 268500 & 5.21 \\
\hline
\end{tabular}

planted rice followed by zero tilled wheat system, decreased cost of cultivation by $21 \%$ and increased grain yield by $5 \%$ over puddle transplanted rice followed by conventionally tilled wheat treatment. The $\mathrm{B}$ : $\mathrm{C}$ ratio of puddle transplanted rice followed by zero tilled wheat was 4.65 while that of puddle transplanted rice followed by conventionally tilled wheat system was 3.24, whereas B: C ratio of cauliflower under vegetable on bed in both seasons was 5.21, while that of conventionally tilled jowar followed by conventionally tilled wheat system was 2.35 . Thus, it was concluded that zero till wheat in fine textured soils of low lying lands and seasonal vegetables (e.g. cauliflower as test crop in the present study) on beds were best conservation agricultural options for higher yield and profitability along with less consumption of time, energy, money and labour.

\section{REFERENCES}

Aggarwal, P. and Goswami, B. (2003). Bed planting system for increasing water use efficiency of wheat grown on Inceptisol. Indian Journal of Agricultural Sciences 73: 
$422-425$.

Duxbury, J.M., Abrol, I.P., Gupta, R.K. and Bronson, K.F. (2000). Analysis of long-term fertility experiments with rice-wheat rotations in South Asia. In: Abrol, I.P., Bronson, K.F., Duxbury, J.M., Gupta, R.K. (Eds.), Long -term Soil Fertility Experiments in Rice-Wheat Cropping Systems. Rice-Wheat Consortium Paper Series 6 . RWC, New Delhi, India 7-21.

Ekboir, J. (2002). Developing no-till packages for small -scale farmers. In: Ekboir, J. (Ed.), CIMMYT 20002001 World Wheat Overview and Outlook. CIMMYT, Mexico, DF, pp. 1-38.

Erenstein, O. (2002). Crop residue mulching in tropical and semi-tropical countries: an evaluation of residue availability and other technological implications. Soil and Tillage Research, 67: 115-133.

Erenstein, O. (2003). Smallholder conservation farming in the tropics and subtropics: a guide to the development and dissemination of mulching with crop residues and cover crops. Agriculture, Ecosystems and Environment, 100: $17-37$.

Erenstein, O. (2009) Adoption and impact of conservation agriculture based resource conserving technologies in South Asia. In Proceedings of the $4^{\text {th }}$ world congress on conservation agriculture, February 4-7, 2009, New Delhi, India. New Delhi: World Congress on Conservation Agriculture, 20.

Gangwar, K.S., Singh, K.K., Sharma, S.K. and Tomar, O.K. (2006). Alternative tillage and crop residue management in wheat after rice in sandy loam soils of Indo-Gangetic Plains. Soil \& Tillage Research, 88: 242-252.

Gomez, A.K. and Gomez, A.A. (1984). Statistical Procedures for Agricultural Research, 2nd ed. John Wiley \& Sons, New York, pp. 180-209.

Gupta, R, Ravi Gopal, Jat, M.L., Jat, R.K., Sidhu, H.S., Minhas, P.S. and Malik, R.K. (2010). Wheat productivity in Indo -Gangetic plains of India during 2010: Terminal heat effects and mitigation strategies. PACA News 1tr., p. 1-3.

Gupta, R.K., Naresh, R.K., Hobbs, P.R. and Ladha, J.K., (2002). Adopting conservation agriculture in the ricewheat system of the Indo-Gangetic Plains: new opportunities for saving water. In: Bouman, B.A.M., Hengsdijk, H., Hardy, B., Bindraban, P.S., Tuong, T.P., Ladha, J.K. (Eds.), Water wise rice production. Proceedings of the international workshop on water wise rice production, April 8-11, 2002, Los Banos, Philippines. International Rice Research Institute, Los Banos (Philippines), pp. 207-222.

Hobbs, P. and Gupta, R. (2003). Problems and Challenges of No-Till Farming for the Rice-Wheat Systems of the
Indo-Gangetic Plains in South Asia. In Lal, R., Hobbs, P., Hansen, D.O., and Uphoff, N. (eds.), Sustainable Agriculture and the Rice-Wheat System, Marcel Dekker, New York, in press.

Kankanen, H., Alakukkub, L. and Pitkanena, T. (2011). Growth and yield of spring cereals during transition to zero tillage on clay soils. Europ. J. Agronomy, 34: 35-45.

Kumar, R., Aggarwal, P., Singh, R., Chakraborty, D., Bhattacharya, R., Garg, R.N., Kamble K. H. and Yadav, B. (2014). Assessment of soil physical health and productivity of Kharkhoda and Gohana blocks of Sonipat district (Haryana), India. Journal of Applied and Natural Science 6: 6-11.

Ladha, J.K., Dawe, D., Pathak, H., Padre, A.T. and Yadav, R.L. (2003). How extensive are yield declines in long-term rice-wheat experiments in Asia. Field Crops Res., 81: 159-180.

NHB (2014). National Horticulture Board Database, Ministry of Agriculture, Govt of India. Pp 148-149.

Sharma, R.K., Chhokar, R.S., Jat, M.L., r Singh, S., Mishra, B. and Gupta, R.K. (2006). Direct drilling of wheat into rice residues: experiences in Haryana and Western Uttar Pradesh. In "Permanent Bed and rice-residue management for rice-wheat systems in the Indo-Gangetic Plain" (eds: E Humphreys and $\mathrm{CH}$ Roth). Proceedings of a workshop held at PAU, Ludhiana, India from 7-9 September 2006. ACIAR Proceedings No. 127. Pp 147-158.

Sharma, P.K. and Bhushan, L. (2001). Physical characterization of a soil amended with organic residues in a rice -wheat cropping system using a single value soil physical index. Soil Tillage Res., 60: 143-152.

Singh, P., Sweta Singh, S., Singh, B.R. and Mishra, D.K. (2014). Performance Evaluation of Zero -Till Ferti-Seed Drill in Comparison to Conventional and Reduced Tillage Methods of Wheat Crop on the Same Day International Journal of Scientific and Research Publications, 4 (8): $1-4$

Sidhu, R.S., Kumar, S., Vatta, K. and Singh, P. (2010). Supply Chain Analysis of Onion and Cauliflower in Punjab. Agricultural Economics Research Review, 23: 445-453.

Timsina, J. and Connor, D.J. (2001). Productivity and management of rice-wheat cropping systems: issues and challenges. Field Crop Res., 69, 93-132.

Weinberger, K. and Lumpkin. T.A. (2006). High value agricultural products in Asia and the Pacific for smallholder farmers: Trends, opportunities and research priorities. 32. GFAR Occasional Paper Series, Rome: GFAR. 